\title{
Life cycle greenhouse gas emissions analysis of catalysts for hydrotreating of fast pyrolysis bio-oil
}

\author{
LJ Snowden-Swan ${ }^{\mathrm{a} *}$, KA Spies ${ }^{\mathrm{a}}$, GJ Lee ${ }^{\mathrm{a}}$, and Y Zhu ${ }^{\mathrm{a}}$
}

${ }^{\text {a} P a c i f i c ~ N o r t h w e s t ~ N a t i o n a l ~ L a b o r a t o r y, ~ R i c h l a n d, ~ W A, ~ U S A ~}$

*Corresponding author. lesley.snowden-swan@pnnl.gov Tel: 1509933 2145. Fax: 15093724732. 


\section{Abstract}

2 Bio-oil from fast pyrolysis of biomass requires multi-stage catalytic hydroprocessing to produce

3 hydrocarbon drop-in fuels. One process design currently in development involves fixed beds of

4 ruthenium-based catalyst and conventional petroleum hydrotreating catalyst. As the catalyst is spent over

5 time as a result of coking and other deactivation mechanisms, it must be changed out and replaced with

6 fresh catalyst. A main focus of bio-oil upgrading research is increasing catalyst lifetimes to 1 year.

7 Biofuel life cycle greenhouse gas (GHG) assessments typically ignore the impact of catalyst consumed

8 during fuel conversion as a result of limited lifetime, representing a data gap in the analyses. To help fill

9 this data gap, life cycle GHGs were estimated for two representative examples of fast pyrolysis bio-oil

10 hydrotreating catalyst, $\mathrm{NiMo} / \mathrm{Al}_{2} \mathrm{O}_{3}$ and $\mathrm{Ru} / \mathrm{C}$, and integrated into the conversion-stage GHG analysis.

11 Life cycle GHGs are estimated at $5.5 \mathrm{~kg} \mathrm{CO}$-e/kg catalyst for $\mathrm{NiMo} / \mathrm{Al}_{2} \mathrm{O}_{3}$. Results vary significantly for

$12 \mathrm{Ru} / \mathrm{C}$, depending on whether economic or mass allocation methods are used. Life cycle GHGs for Ru/C

13 are estimated at $80.4 \mathrm{~kg} \mathrm{CO} \mathrm{CO}_{2}$-e/kg catalyst using economic allocation and $13.7 \mathrm{~kg} \mathrm{CO}$-e/kg catalyst using

14 mass allocation. Contribution of catalyst consumption to total conversion-stage GHGs at 1-year catalyst

15 lifetimes is $0.5 \%$ for $\mathrm{NiMo} / \mathrm{Al}_{2} \mathrm{O}_{3}$ and $5 \%$ for $\mathrm{Ru} / \mathrm{C}$ when economic allocation is used ( $1 \%$ for mass

16 allocation). This analysis does not consider the use of recovered metals from catalysts and other wastes

17 for catalyst manufacture and therefore these are likely to be conservative estimates compared to

18 applications where a spent catalyst recycler can be used.

20 Keywords: biofuel; catalyst; bio-oil; hydrotreating; life cycle analysis; greenhouse gas 


\section{1. Introduction}

22 Raw pyrolysis oil from biomass is an unsuitable feedstock for direct insertion into a petroleum refinery

23 because it contains excess moisture and high levels of heteroatoms, primarily oxygen, compared to

24 petroleum crude oil. The bio-oil must first be processed via hydrodeoxygenation to produce a

25 hydrocarbon mixture more amenable to fungible transportation fuels production. Years of research at

26 Pacific Northwest National Laboratory (PNNL) and by other entities have led to the development of a

27 general multi-stage catalytic hydrotreating scheme for the successful upgrading of bio-oil into

28 transportation fuels [1]. Several catalysts have been studied for this developing process, including

29 conventional petroleum hydrotreating catalysts such as NiMoS and CoMoS, and newer catalysts such as

$30 \mathrm{Ru} / \mathrm{C}$ [1],[2]. Research at PNNL on pyrolysis bio-oil upgrading has focused on improving reactor stability

31 and testing and developing improved catalysts to achieve optimal technical and cost performance.

In addition to the economical production of renewable cellulosic biofuels, a measure of the overall

33 sustainability of these fuel production pathways is of critical importance. To ensure that biofuels are more

34 renewable and less impactful than the fossil fuels they are designed to replace, the Renewable Fuel

35 Standard (RFS2), as legislated by the 2007 Energy Independence and Security Act (EISA 2007) [3],

36 requires a minimum life cycle greenhouse gas (LC GHG) savings that biofuels must achieve over the

37 status quo. The minimum LC GHG savings for fuels made from renewable biomass are a reduction of

$3850 \%$ (advanced) or $60 \%$ (cellulosic) compared with the petroleum baseline. ${ }^{1}$ Several studies have

39 estimated LC GHGs for fuels from fast pyrolysis and upgrading, but they have overlooked the impact of

40 catalyst consumption by either ignoring it completely or using a proxy [5]-[7]. This data gap needs to be

41 addressed in order to assess the contribution of catalyst consumption to the overall fuel cycle GHGs for

42 the pathway.

\footnotetext{
${ }^{1}$ As determined by the US Environmental Protection Agency, the 2005 baseline GHGs for petroleum gasoline and diesel are $93.08 \mathrm{gCO}_{2}$-e/MJ and $91.94 \mathrm{gCO}_{2}$-e/MJ, respectively [4].
} 
While the catalysts most likely to be used for hydrodeoxygenation are expected to be variants of

44 commercially available hydrotreating catalysts, very little in the way of life cycle analysis of chemical

45 processing catalysts has been published in the open literature. The goal of this study is to quantify the

46 GHG emissions associated with production of two representative examples of bio-oil hydrotreating

47 catalysts, $\mathrm{NiMo} / \mathrm{Al}_{2} \mathrm{O}_{3}$ and $\mathrm{Ru} / \mathrm{C}$, and to determine the contribution of catalyst consumption to the $\mathrm{LC}$

$48 \quad$ GHGs attributed to the fast pyrolysis and upgrading conversion process.

\section{$49 \quad 2 . \quad$ Life cycle assessment methods}

50 Life cycle assessment (LCA) has become the predominant tool for evaluating and comparing the

51 environmental impact of processes and products. If applied early in the design stages and throughout

52 research and development, it can be used to design a "greener" product than otherwise might be produced.

53 LCA accounts for all inflows and outflows of all stages of a product's supply chain, from extraction of

54 natural (raw) materials to the final fate of the product. The methodology in theory includes all aspects of

55 environmental impact, providing a holistic approach to product assessment. As such, a complete LCA

56 evaluates multiple impact categories; some of the more commonly used ones are global warming, ozone

57 depletion, resource depletion, photochemical smog, acidification, human health, terrestrial toxicity,

58 aquatic toxicity, eutrophication, land use, and water use. All of these indicators, along with economic and

59 social implications, need to be evaluated during technology development to facilitate the most sustainable

60 outcome. While LCA is a strong tool for a wide range of sustainability indicators, this study focuses only

61 on global warming potential (GWP) because it is central to determining whether a fuel meets RFS2 fuel

62 definitions. The scope of the LCA for this study is global warming, represented in grams of $\mathrm{CO}_{2^{-}}$

63 equivalents $\left(\mathrm{CO}_{2}\right.$-e) using a 100-year GWP [8].

\section{$64 \quad 2.1 \quad$ Goal and functional unit}

65 The goal of this study is to estimate the LC GHG emissions associated with production of two

66 representative examples of candidate bio-oil hydrotreating catalysts that may be used for pyrolysis oil

67 upgrading: a sulfided $\mathrm{Ni} / \mathrm{Mo}$ on $\mathrm{Al}_{2} \mathrm{O}_{3}$ and $\mathrm{Ru} / \mathrm{C}$. The study results are intended to inform the LC GHG 
analysis for biofuels from pyrolysis and upgrading and to determine the relative impact of catalyst

72 (“cradle to gate”).

\section{3}

74 consumption for this pathway. Results may also help to inform other, related fuel production routes under development that are based on bio-oil upgrading (e.g., from hydrothermal liquefaction and catalytic fast pyrolysis). The functional unit for this study is $1 \mathrm{~kg}$ of fresh catalyst produced at the manufacturing plant

\section{$2.2 \quad$ System boundaries}

Fig. 1 shows the complete bio-oil catalyst life cycle and how it contributes to the overall fuel supply chain. For the focus of this study, the catalyst life cycle begins with mining and extraction of metals and raw materials, includes the refining and processing of the raw materials, and ends with the production of the catalyst. A case could be made for including catalyst recycling, regeneration, and metal reclamation; however, due to large variability in the processing of spent catalyst and the lack of current data for those processes, they were excluded from this analysis. The scope of this analysis is limited to estimation of GHGs associated with manufacture of $1 \mathrm{~kg}$ of fresh catalyst. The impact of these results on the conversion-stage GHGs for fuels produced from biomass fast pyrolysis and bio-oil upgrading is also presented in the results section. Multi-stage hydrotreating of pyrolysis oil for production of transportation fuels uses increased processing severity (temperature and pressure) with each stage, a design that reduces the overall coking in the system [1]. The first stage (stabilizer) and second stage use a ruthenium-based catalyst and the third stage uses a sulfided molybdenum-based catalyst [5]. Although the exact catalyst compositions for commercial application are still under development, a Ru/C catalyst and a pre-sulfided $\mathrm{MoS}_{2} / \mathrm{NiS}$ on alumina were chosen as representative examples with the expectation that the analysis will need to be refined as more becomes known about bio-oil hydrotreating catalysts.

\subsection{Modeling and data collection}

The LCA software, SimaPro [9], is used to model the catalyst life cycle. The data for the study comes from a variety of sources, including studies from metal industry trade organizations, engineering calculations and process modeling based on literature and patents, and databases included in the SimaPro 
package (Ecoinvent Versions 2.2 [10] and 3.1 [11], US Life Cycle Inventory (LCI) [12], US-EI [13], and

94 European reference Life Cycle Database (ELCD) [14]). 115 feedstock [20].

\subsubsection{Metals and precursor production}

The production of catalyst-grade metal compounds generally consists of four steps: (1) mining, (2) beneficiation (grinding and crude separation), (3) primary extraction, and (4) refining [15]. The ore mining occurs both underground and in open pits around the world. Typically, the ore occurs in metal concentrations that are too low for direct smelting, so it must undergo beneficiation [16],[17]. The beneficiation process can involve the mechanical pulverization of ores, which are separated by density or magnetic qualities. After beneficiation, the material undergoes primary extraction, which includes smelting, leaching, calcining, and other processes to concentrate the metal. The final refining step separates the desired metal from other metals and impurities.

\subsubsection{Nickel and molybdenum}

There are three primary raw materials used for the production of nickel/molybdenum catalyst: molybdenum trioxide $\left(\mathrm{MoO}_{3}\right)$, nickel oxide $(\mathrm{NiO})$, and alumina $\left(\mathrm{Al}_{2} \mathrm{O}_{3}\right)$ [18]. The product overall inventory for $\mathrm{MoO}_{3}$ was obtained directly from a study by the International Molybdenum Association (IMOA) [19]. The inventory was determined from [19] and is aggregated to include mining of Mo through the manufacture of $\mathrm{MoO}_{3}$. From the inventory, an aggregated GHG emissions value of $10.8 \mathrm{~kg}$ $\mathrm{CO}_{2}$-e/kg $\mathrm{MoO}_{3}$ was calculated using the Intergovernmental Panel on Climate Change (IPCC) 2007 GWP 100a v1.02 method included in the SimaPro package. The GHG emissions value used for the NiO is taken from the Nickel Institute's estimate of 21,547 $\mathrm{g} \mathrm{CO}_{2}$-eq $/ \mathrm{kg} \mathrm{NiO}$ [15]. The majority of the GWP for NiO results from the energy used during primary extraction, which consists of smelting for the nickel ore portion of the feedstock, and solvent extraction followed by calcination for the nickel liquor portion of the 


\subsubsection{Ruthenium}

117 The ruthenium catalyst uses a $2.8 \mathrm{wt} \%$ loading of ruthenium on a carbon support. Ruthenium is a

118 platinum group metal (PGM) that is produced as a co-product of platinum and palladium production,

119 primarily in South Africa and Russia [21]. PGMs consist of platinum, palladium, rhodium, ruthenium,

120 iridium, and osmium and are often found with nickel $(\mathrm{Ni})$, copper $(\mathrm{Cu})$, and gold $(\mathrm{Au})$. The worldwide

121 supply of PGMs is much more limited than nickel or other common metals and they exist in very small

122 concentrations. Related to this, PGMs are regarded as "critical” materials, meaning that they are crucially

123 important for society, yet are associated with a high supply risk [22]. While ruthenium has less

124 commercial use than other PGMs, it has applications in catalysts for chemical synthesis and for electrode 125 coatings [23].

Information specific to energy use and GHG emissions of ruthenium mining and processing is

127 extremely limited in the literature. To overcome this data gap, the life cycle inventory for ruthenium ore was estimated based on PGM production inventories developed by Ecoinvent [10] for Russia and South Africa. The updated Ecoinvent Version 3 dataset [11] was chosen for estimating PGM inventory because

130 it includes an important update to the electricity mix used for the South African operations. For

131 consistency, the Version 3 dataset for Russia was also used. The dataset for primary PGMs ${ }^{2}$ covers

132 production of virgin $\mathrm{Pt}, \mathrm{Pd}, \mathrm{Rh}$, with $\mathrm{Ni}$, and $\mathrm{Cu}$ co-products and is aggregated to include all upstream

133 processes leading up to and including the final PGM refining process (mining, beneficiation, metallurgy, 134 separation, and refining). Two alternative methods of allocation were considered: economic and mass. In 135 economic allocation, the portion of the life cycle emissions inventory allocated to each PGM is based on 136 the revenue generated from each PGM relative to the total product ore from the process [23]. This form of 137 impact allocation is an approach commonly applied to the mining/metals industry [24]-[29] and is 138 recommended for consideration in cases where the prices of co-products differ widely [30] as in the case

\footnotetext{
2 "Platinum group metal production, primary, ZA (South Africa)”; “Platinum group metal production, primary, RU (Russia).”
} 
of PGM production. The rationale for using economic allocation is that industrial operations are driven by

140 revenue generation, and in this type of situation mass allocation fails to adequately capture the main

141 purpose of processing [29]. As shown in Fig. 2, PGM prices can fluctuate significantly, making it

142 necessary to update economically allocated analyses periodically with more recent market prices. Results

143 using mass allocation, where energy and emissions burdens are allocated based on the composition of the

144 ore, are also presented for comparison.

145 For estimating emissions associated with Ru, the Ecoinvent 3.1 primary PGM processes for South

146 African and Russian production were modified to include Ru in the PGM mix, with the remainder of

147 PGM components (Pt, Pd, and Rh) normalized using the same relative proportions of Pt, Pd and $\mathrm{Rh}$ as are

148 in the original Ecoinvent 3.1 process. The concentration of $\mathrm{Ru}$ in the ore is assumed to be $0.44 \mathrm{ppm}$ for

149 South African ore [23] and 0.3 ppm for Russian ore [17]. In addition, the process economic allocations

150 were updated with the 5-year average prices (shown in Fig. 2) to reflect more current prices. The resulting

151 PGM product mix, co-product allocations, and GHG estimates per kilogram of metal (using the IPCC

152 GWP 100a v1.02 method) are given in Tables 1 and 2. Using economic allocation, the resulting total

153 PGM GHG intensities for production in South Africa and Russia are 26,100 kg CO 2 -e/kg PGM and

154 11,800 kg CO 2 -e/kg PGM, respectively. Using mass allocation, the resulting total PGM GHG intensities

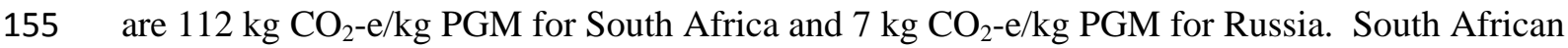

156 production is high relative to Russian production, due primarily to the prevalence of inefficient coal-fired

157 power plants in South Africa [26]. It is assumed that the source mix of Ru used in catalyst precursor

158 production $\left(\mathrm{RuCl}_{3}\right)$ is the same as that for primary $\mathrm{Rh}$ included in the global $\mathrm{Rh}$ market in Ecoinvent 3.1.

159 [11]: 78\% from South Africa and 22\% from Russia. Secondary (recycled) Ru is not considered in the 160 analysis. 
Table 1 - Primary PGM product composition, allocation and GHGs, South Africa.

\begin{tabular}{|c|c|c|c|c|c|c|c|c|c|}
\hline \multirow[b]{2}{*}{ Metal } & \multicolumn{4}{|c|}{ Ecoinvent (v3.1) } & \multicolumn{5}{|c|}{ This Analysis } \\
\hline & $\begin{array}{l}\text { tonne/ } \\
\text { tonne } \\
\text { PGM }^{\mathrm{a}}\end{array}$ & $\begin{array}{l}\text { \$/troy } \\
\mathrm{oz}^{\mathrm{b}}\end{array}$ & $\begin{array}{c}\text { Economic } \\
\text { Allocation } \\
(\%)\end{array}$ & $\underset{\text { metal }^{\mathrm{kg} \mathrm{CO}}}{\mathrm{kg}}$ & $\begin{array}{l}\text { tonne/ } \\
\text { tonne } \\
\text { PGM }\end{array}$ & $\begin{array}{l}\text { \$/troy } \\
\text { oz }^{\mathrm{d}}\end{array}$ & $\begin{array}{c}\text { Economic } \\
\text { Allocation } \\
(\%)\end{array}$ & $\begin{array}{l}\mathrm{kg} \mathrm{CO}_{2^{-}} \\
\mathrm{e} / \mathrm{kg} \mathrm{metal}^{\mathrm{c}} \\
\text { (with econ. } \\
\text { allocation) }\end{array}$ & $\begin{array}{c}\text { Mass } \\
\text { Allocation } \\
\text { (\%) }\end{array}$ \\
\hline Nickel & 147 & 0.39 & 8 & 16.2 & 147 & 0.49 & 5.4 & 10.3 & 58.3 \\
\hline Copper & 104 & 0.09 & 1 & 3.41 & 104 & 0.24 & 1.9 & 5.07 & 41.3 \\
\hline Palladium & 0.29 & 210 & 9 & 8,776 & 0.27 & 658 & 13.5 & 13,898 & 0.11 \\
\hline Platinum & 0.68 & 762 & 77 & 32,055 & 0.64 & 1561 & 75.2 & 32,978 & 0.26 \\
\hline Rhodium & 0.03 & 885 & 4 & 37,035 & 0.03 & 1652 & 3.5 & 35,335 & 0.01 \\
\hline Ruthenium & - & - & - & - & 0.06 & 127 & 0.5 & 2,665 & 0.02 \\
\hline
\end{tabular}

163

\begin{tabular}{|c|c|c|c|c|c|c|c|c|c|}
\hline \multirow[b]{2}{*}{ Metal } & \multicolumn{4}{|c|}{ Ecoinvent (v3.1) } & \multicolumn{5}{|c|}{ This Analysis } \\
\hline & $\begin{array}{l}\text { tonne/ } \\
\text { tonne } \\
\text { PGM }^{\text {a }}\end{array}$ & $\begin{array}{c}\$ / \text { troy } \\
\mathrm{oz}^{\mathrm{b}}\end{array}$ & $\begin{array}{c}\text { Economic } \\
\text { Allocation } \\
(\%)\end{array}$ & $\begin{array}{c}\mathrm{kg} \mathrm{CO}-\mathrm{e} / \mathrm{kg} \\
\text { metal }^{\mathrm{c}}\end{array}$ & $\begin{array}{c}\text { tonne/ } \\
\text { tonne } \\
\text { PGM }\end{array}$ & $\begin{array}{c}\text { \$/troy } \\
\mathrm{oz}^{\mathrm{d}}\end{array}$ & $\begin{array}{c}\text { Economic } \\
\text { Allocation } \\
(\%)\end{array}$ & $\begin{array}{l}\mathrm{kg} \mathrm{CO}_{2^{-}} \\
\mathrm{e} / \mathrm{kg} \mathrm{metal}^{\mathrm{c}} \\
\text { (with econ. } \\
\text { allocation) }\end{array}$ & $\begin{array}{c}\text { Mass } \\
\text { Allocation } \\
(\%)\end{array}$ \\
\hline Nickel & 2310 & 0.39 & 59 & 9.49 & 2310 & 0.49 & 40.5 & 6.52 & 41.9 \\
\hline Copper & 3200 & 0.09 & 17 & 2 & 3200 & 0.24 & 27.7 & 3.23 & 58.1 \\
\hline Palladium & 0.73 & 210 & 10 & 5,148 & 0.71 & 658 & 16.8 & 8,842 & $12.8 \mathrm{e}-3$ \\
\hline Platinum & 0.25 & 762 & 13 & 18,805 & 0.24 & 1561 & 13.7 & 20,983 & $4.4 \mathrm{e}-3$ \\
\hline Rhodium & 0.02 & 885 & 1 & 21,726 & 0.02 & 1652 & 1.2 & 22,257 & $3.5 e-4$ \\
\hline Ruthenium & - & - & - & - & 0.03 & 127 & 0.1 & 1,737 & $5.4 \mathrm{e}-4$ \\
\hline
\end{tabular}

${ }^{a}$ Classen et al. [23].

${ }^{\mathrm{b}}$ Ecoinvent Version 3, 2014 (ecoquery.ecoinvent.org).

${ }^{\mathrm{c}}$ Using IPCC GWP 100a v1.02 method in SimPro 8.0.

${ }^{\mathrm{d}}$ Average price for 9-1-2009 through 9-1-2014 (Johnson Matthey PGM Price Tables 2014 [31]).

165

166

167

168

169

170

Table 2 - Primary PGM product composition, allocation and GHGs, Russia.

Ru catalyst can be made with various precursors such as $\mathrm{RuCl}_{3}, \mathrm{Ru}\left(\mathrm{NO}_{3}\right)\left(\mathrm{NO}_{3}\right)$, and $\mathrm{Ru}(\mathrm{acac})_{3}$. $\mathrm{RuCl}_{3}$ was selected as the precursor material, as it has been shown to result in a high activity and a low rate of reduction in metal dispersion and pore volume [32]. Ruthenium is purified by reacting it with chlorine gas to form $\mathrm{RuCl}_{3}$, and it is typically sold in that form. Inventory for chlorine gas used in $\mathrm{RuCl}_{3}$ production was used without modification from the Ecoinvent Version 2.2 database [10]. As the process 
171 energy for production of $\mathrm{RuCl}_{3}$ is not available in the literature, an estimate was made based on enthalpy.

172 The heat required to overcome system losses to the environment was not considered in the estimate.

173 The process for synthesis of $\mathrm{RuCl}_{3}$ is assumed to occur via the reaction [33]:

$181.8 \mathrm{~kJ} / \mathrm{mol}$ of $\mathrm{RuCl}_{3}$ product. Assuming a 50\% heating efficiency, this results in a heating load of 0.101

$177 \mathrm{kWh} / \mathrm{mol}$ or $0.487 \mathrm{kWh} / \mathrm{kg}$. This energy requirement was assumed to be provided by the average US grid 178 mix used in the Ecoinvent Version 2.2 database, as listed in Table 3.

179

180

181

182

183

184

\section{Table 3 - Assumed US electricity grid mix (Ecoinvent 2.2).}

\begin{tabular}{lc}
\hline \multicolumn{1}{c}{ Resource } & $\%$ \\
\hline Coal & 50 \\
Nuclear & 20 \\
Natural Gas & 17 \\
Renewables & 10 \\
Oil/Industrial Gas & 3 \\
\hline
\end{tabular}

The carbon support traditionally used for Ru/C catalyst is likely generated from a biomass source such as coconut shells due to its high crush strength and high surface area. However, as data for coconutshell-based carbon could not be found in the literature, coal-based carbon was used as a proxy, the GHG emissions for which are taken from Bayer et al. [35]. This activated carbon is produced by grinding coal, mixing with binding agent, briquette production, drying, carbonization, activation, crushing, sieving, and packaging, resulting in a GWP of $11.0 \mathrm{~kg} \mathrm{CO} \mathrm{CO}_{2}$-e/kg virgin granulated activated carbon [35].

\subsubsection{Catalyst synthesis and preparation}

The most likely catalysts for hydrotreating bio-oil are produced commonly by incipient wetness impregnation [36]-[38]. The active metal and ligand precursor is dissolved in an aqueous or non-aqueous solvent and is added to a porous support. Capillary action from the pores draws the metal solution into the pores. After the solution is applied, the catalyst is dried to remove the solvent. The desired loading is 
achieved by multiple solution and drying steps and by concentrating the metal solution. After the final

194 drying, the catalyst is calcined at high temperature to remove the ligand from the metal atoms. Some 195 hydrotreating catalysts must also be sulfidated.

\subsubsection{1 $\mathrm{MoS}_{2} / \mathrm{NiS}$ on $\mathrm{Al}_{2} \mathrm{O}_{3}$}

197 Life cycle inventory data for synthesis of $\mathrm{MoS}_{2} / \mathrm{NiS}$ on $\mathrm{Al}_{2} \mathrm{O}_{3}$ was developed based on steps described in 198 a Shell Oil Company patent [18] and is shown in Fig. 3. The catalyst modeled in this process is $13.6 \mathrm{wt} \%$ $199 \mathrm{MoS}_{2}$ and $9.1 \mathrm{wt} \% \mathrm{NiS}$ on $\mathrm{Al}_{2} \mathrm{O}_{3}$. The process material and energy balance is scaled from a batch-wise 200 process operating at bench scale, so it may be significantly different from an actual manufacturing setting 201 (e.g., with continuous production, heat integration, and different primary energy sources). However, 202 where available, the best information for process data was used. The product is sulfided ex-situ and 203 therefore pre-sulfiding is not necessary at the refinery. Ex-situ sulfiding is indicated as the preferred 204 choice in the Shell patent [18]. The use of pre-sulfided hydroprocessing catalysts has gained increasing 205 favor in the refining industry, due to reduced start-up time and higher catalyst activity [39]-[41]. The actiCAT ${ }^{\circledR}$ process is used for ex-situ sulfiding, which consists of treating the catalyst with elemental

207 sulfur and then heating in the presence of liquid olefinic hydrocarbon (assumed to be diesel) and hydrogen to produce metal sulfides. High-temperature calcination is not needed with this process.

In addition to metal and support, there are several system inputs for the production of the final catalyst. The diesel used in the sulfiding and activation steps is assumed to be completely recycled with

211 no makeup required (start-up diesel is ignored). Hydrogen used in the activation step is assumed to be 212 purchased. GHGs associated with hydrogen use are estimated from the GREET model [42]. All other raw 213 materials and energy needed for catalyst production $\left(\mathrm{H}_{3} \mathrm{PO}_{4}\right.$, sulfur, natural gas, electricity, steam) come 214 from the Ecoinvent Version 3.1 database [11].

215 The catalyst production process was modeled using the commercial process flow simulation 216 software Aspen Plus (Version 8.4 [43]) and energy consumption was estimated from the results of the 217 model. The assumptions for the catalyst preparation stage, including energy estimations from the Aspen 
model, are given in Table 4. Industrially relevant energy sources for heating steps were chosen for the

model. For example, for heating processes below about 100C, low quality steam is most often used.

220 Above about 250C, natural gas is the most appropriate choice. The average US grid mix is assumed for

221 the electricity usage in the analysis[10] (see Table 3). Sensitivity analysis is conducted for cases where

222 all manufacturing energy in Table 4 is assumed to be electricity and the electricity grid mix is varied

223 according to different regions of the U.S.

Table 4 - Primary assumptions for manufacture of $\mathrm{MoS}_{2} / \mathrm{NiS}$ on $\mathrm{Al}_{2} \mathrm{O}_{3}$ catalyst.

\begin{tabular}{|c|c|c|c|}
\hline Process Energy Step & $\begin{array}{l}\text { Energy Use } \\
\text { (kJ per kg } \\
\text { catalyst) }\end{array}$ & Energy Type & LCI/GHG Source \\
\hline $\begin{array}{l}\mathrm{Al}_{2} \mathrm{O}_{3} \\
\text { drying/calcination }\end{array}$ & 416.8 & natural gas & $\begin{array}{l}\text { Natural gas, burned in industrial furnace }>100 \\
\text { kW/RER with US Electricity U (US-EI 2.2) }\end{array}$ \\
\hline Overall cooling water & -3358.0 & $\begin{array}{l}160.8 \mathrm{~kg} 20^{\circ} \mathrm{C} \text { cooling } \\
\text { water fed, } 5^{\circ} \mathrm{C} \text { gain }\end{array}$ & Water, process, unspecified natural origin $/ \mathrm{m}^{3}$ \\
\hline Dissolution & 206.0 & steam & $\begin{array}{l}\text { Process steam from natural gas, heat plant, } \\
\text { consumption mix, at plant, MJ EU-27 S } \\
\text { (ELCD) }\end{array}$ \\
\hline Precursor drying & 1656.9 & steam & $\begin{array}{l}\text { Process steam from natural gas, heat plant, } \\
\text { consumption mix, at plant, MJ EU-27 S } \\
\text { (ELCD) }\end{array}$ \\
\hline Sulfiding and activation & 485.6 & natural gas & $\begin{array}{l}\text { Natural gas, burned in industrial furnace }>100 \\
\text { kW/RER with US Electricity U (US-EI 2.2) }\end{array}$ \\
\hline Solvent recycle & 14.9 & electricity & $\begin{array}{l}\text { Electricity, medium voltage, at grid/US with } \\
\text { US Electricity U (US-EI 2.2) }\end{array}$ \\
\hline Final catalyst drying & 1266.9 & natural gas & $\begin{array}{l}\text { Natural gas, burned in industrial furnace > } \\
\text { 100kW/RER with US Electricity U (US-EI } \\
2.2 \text { ) }\end{array}$ \\
\hline Material Input & $\begin{array}{l}\text { Mass }(\mathrm{g} / \mathrm{kg} \\
\text { catalyst) }\end{array}$ & Comment & LCI/GHG Source \\
\hline $\mathrm{Al}_{2} \mathrm{O}_{3}$ & 772.2 & $\begin{array}{l}1.2 \mathrm{~mm} \text { trilobe } \\
\text { extrudate; } 100 \% \text { yield }\end{array}$ & Alumina, at plant NREL/US (US EI 2.2) \\
\hline Water & 617.7 & & $\begin{array}{l}\text { Water, deionized, at plant/CH with US } \\
\text { electricity U }\end{array}$ \\
\hline $\mathrm{H}_{3} \mathrm{PO}_{4}$ & 34.9 & $\begin{array}{l}14.8 \text { molar phosphoric } \\
\text { acid }\end{array}$ & $\begin{array}{l}\text { Phosphoric acid, industrial grade, } 85 \% \text { in } \mathrm{H}_{2} \mathrm{O} \text {, } \\
\text { at plant/RER with US electricity U (US-EI } \\
\text { 2.2) }\end{array}$ \\
\hline $\mathrm{MoO}_{3}$ & 136.0 & $90 \%$ yield & IMOA [19] \\
\hline $\mathrm{NiO}$ & 83.4 & $90 \%$ yield & Nickel Institute [13] \\
\hline Sulfur & 97.3 & Elemental sulfur & $\begin{array}{l}\text { Secondary sulphur, at refinery/RER with US } \\
\text { electricity U (US EI 2.2) }\end{array}$ \\
\hline Hydrogen & 8.8 & Pressurized gas, 900 psi & GREET [42](13,655 g CO $_{2}$-e/kg H 2$)$ \\
\hline Diesel & 1301.0 & $\begin{array}{l}\text { Assumed to be } 100 \% \\
\text { recycled }\end{array}$ & \\
\hline
\end{tabular}




\section{$226 \quad$ 2.3.2.2 $\mathrm{Ru} / \mathrm{C}$}

227 The catalyst modeled in this analysis contains a $2.8 \mathrm{wt} \%$ loading of ruthenium on a carbon support. Life 228 cycle inventory for synthesis of Ru/C catalyst was developed based on steps described by Wildschut et al. 229 [32]. Similar methods of preparation (with slightly different conditions) are found in [44]-[46]. A model 230 of the catalyst synthesis process was developed with Aspen Plus and is shown in Fig. 4. The design 231 includes six general unit operations. Activated carbon is dried in B1 at $110{ }^{\circ} \mathrm{C}$ for 2 hours to drive off any 232 volatiles present in the source material. The carbon is cooled by $\mathrm{H}-101$ and combined with the $\mathrm{RuCl}_{3}$ and 233 water and mixed in a slurry for 24 hours at $20{ }^{\circ} \mathrm{C}$ and $1 \mathrm{~atm}$. The water is driven from the sample by 234 evaporation at $40{ }^{\circ} \mathrm{C}$ and 30 mbar of pressure in $\mathrm{B} 5$ for 8 hours. After evaporation, the sample is dried at $235100{ }^{\circ} \mathrm{C}$ and 35 mbar of pressure for 12 hours to completely remove any residual solvent. The catalyst is 236 activated by heating under nitrogen atmosphere at $250{ }^{\circ} \mathrm{C}$ for 2 hours. The overall mass balance of the 237 system is shown in Table 5. Energy consumption for each stage of catalyst production was estimated from 238 the results of the model, also listed in Table 5. The average US electricity grid mix from the EcoInvent 239 database is assumed (see Table 3). 
Table 5. Primary assumptions for manufacture of $\mathrm{Ru} / \mathrm{C}$ catalyst.

\begin{tabular}{|c|c|c|c|}
\hline Process Energy Step & $\begin{array}{l}\text { Energy Use (kJ } \\
\text { per kg catalyst) }\end{array}$ & Energy Type & LCI Source \\
\hline Carbon drying & 147.0 & steam & $\begin{array}{l}\text { Process steam from natural gas, heat } \\
\text { plant, consumption mix, at plant, MJ EU- } \\
27 \text { S (ELCD) }\end{array}$ \\
\hline Overall cooling water & -122.2 & $\begin{array}{l}5.85 \mathrm{~kg} 20{ }^{\circ} \mathrm{C} \text { cooling } \\
\text { water fed, } 5{ }^{\circ} \mathrm{C} \text { gain }\end{array}$ & $\begin{array}{l}\text { Water, process, unspecified natural } \\
\text { origin } / \mathrm{m} 3\end{array}$ \\
\hline Solvent Evaporation & 87.3 & electricity & $\begin{array}{l}\text { Electricity, medium voltage, at grid/US } \\
\text { with US Electricity U (US-EI 2.2) }\end{array}$ \\
\hline Drying/Separation & 2370.4 & steam & $\begin{array}{l}\text { Process steam from natural gas, heat } \\
\text { plant, consumption mix, at plant, MJ EU- } \\
27 \text { S (ELCD) }\end{array}$ \\
\hline Activation & 312.0 & natural gas & $\begin{array}{l}\text { Natural gas, burned in industrial furnace > } \\
100 \mathrm{~kW} / \text { RER with US Electricity U (US- } \\
\text { EI 2.2) }\end{array}$ \\
\hline Material Input & $\begin{array}{l}\text { Mass }(\mathrm{g} / \mathrm{kg} \\
\text { catalyst) }\end{array}$ & Comment & LCI/GHG Source \\
\hline Activated carbon & 941.8 & $\begin{array}{l}\text { Coal based as proxy; } \\
100 \% \text { yield }\end{array}$ & $\begin{array}{l}\text { Granular activated carbon (Bayer et al. } \\
\text { [35]) }\end{array}$ \\
\hline Water & 945.4 & & $\begin{array}{l}\text { Water, deionized, at plant/CH with US } \\
\text { electricity U }\end{array}$ \\
\hline $\mathrm{RuCl}_{3}$ & 58.2 & $100 \%$ yield & $\begin{array}{l}\text { Enthalpy calculation }(0.487 \mathrm{kWh} / \mathrm{kg} \\
\text { electrical heat) }\end{array}$ \\
\hline Nitrogen & 2.59 & $\begin{array}{l}\text { Separated from air, low } \\
\text { pressure }\end{array}$ & $\begin{array}{l}\text { Nitrogen, via cryogenic air separation, } \\
\text { production mix, at plant, gaseous EU-27 S }\end{array}$ \\
\hline
\end{tabular}

\section{Results and discussion}

\subsection{Catalyst LC GHGs}

Shown in Fig. 5, the LC GHGs for the $\mathrm{MoS}_{2} / \mathrm{NiS}$ catalyst are estimated to be $5.5 \mathrm{~kg} \mathrm{CO}{ }_{2}-\mathrm{e} / \mathrm{kg}$

catalyst. Production of the precursor materials, alumina, $\mathrm{NiO}$, and $\mathrm{MoO}_{3}$, contributes the majority of GHGs to the total catalyst carbon footprint. There are very few catalyst GHG studies in the literature with

247 which to compare this estimate. Johnson Matthey estimates the LC GHGs for their nickel-based

248 hydrotreating catalyst at $7 \mathrm{~kg} \mathrm{CO} / \mathrm{kg}$ and $8-10 \mathrm{~kg} \mathrm{CO}_{2} / \mathrm{kg}$ for their copper-zinc-based catalysts [47]. The

249 value estimated in this analysis is in the general range of the Johnson Matthey estimate for nickel-based

250 catalyst. Lavery et al. [48] estimates GHGs for sponge nickel catalyst at 25-37 kg CO 2 -e/kg sponge

251 nickel; however, the process used for sponge nickel catalyst production is significantly different from the

252 process used here. To investigate the sensitivity of catalyst GHGs to the energy mix used in the catalyst

253 manufacturing step, additional cases were run for an all-electricity case using the base case mix and 
varying the grid mix corresponding to the North American Electric Reliability Corporation (NERC)

255 regions (in the 48 contiguous states). A map of the NERC regions and their respective mixes are given in 256 Figure 6 and Table 6, respectively [49]. Figure 7 shows the results of the sensitivity analysis. As shown,

257 if electricity is used exclusively at the catalyst production plant, GHGs are 3-13\% higher than the base

258 case energy mix. The case with the lowest GHGs is for the NPCC region, which has the lowest portion of

259 fossil derived power of all the NERC regions. The case with the highest GHGs is for the SPP region,

260 where coal and gas derived power make up $~ 85 \%$ of the grid mix.

Table 6. Electricity generation resource mix for U.S. NERC regions [49].

\begin{tabular}{|c|c|c|c|c|c|c|c|c|}
\hline $\begin{array}{l}\text { Resource, \% } \\
\text { of Grid Mix }\end{array}$ & WECC & MRO & SPP & TRE & RFC & SERC & FRCC & NPCC \\
\hline Coal & 26.19 & 61.26 & 55.37 & 30.51 & 48.72 & 41.11 & 19.42 & 3.11 \\
\hline Oil & 0.38 & 0.24 & 0.56 & 0.95 & 0.48 & 0.47 & 0.64 & 0.38 \\
\hline Gas & 30.26 & 5.35 & 30.15 & 49.05 & 18.02 & 28.26 & 68.06 & 48.55 \\
\hline Other fossil & 0.08 & 0.15 & 0.15 & 0.12 & 0.67 & 0.22 & 0.66 & 1.13 \\
\hline Nuclear & 8.12 & 11.44 & 3.73 & 10.67 & 28.77 & 25.50 & 8.46 & 29.52 \\
\hline Hydro & 25.79 & 5.87 & 1.41 & 0.11 & 0.70 & 2.27 & 0.07 & 11.98 \\
\hline Biomass & 1.32 & 1.60 & 1.06 & 0.20 & 0.90 & 1.84 & 1.76 & 3.63 \\
\hline Wind & 5.20 & 13.84 & 7.52 & 8.29 & 1.66 & 0.24 & --- & 1.64 \\
\hline Solar & 0.43 & --- & 0.05 & 0.03 & 0.04 & 0.01 & 0.09 & 0.03 \\
\hline Other & 0.12 & 0.24 & 0.01 & 0.08 & 0.04 & 0.08 & 0.83 & 0.03 \\
\hline
\end{tabular}

The estimated LC GHGs for the Ru/C catalyst are shown in Fig. 8. When economic allocation is used, LC GHGs are estimated at $80.4 \mathrm{~kg} \mathrm{CO}_{2}$-e/kg catalyst. A large majority of the carbon footprint is due to the production of $\mathrm{RuCl}_{3}$, GHG emissions for which are almost completely attributable to the production of $\mathrm{Ru}$. When mass allocation is used, the estimated LC GHGs are $13.7 \mathrm{~kg} \mathrm{CO}$-e/kg Ru/C, much lower

267 than that estimated using economic allocation. Other than Ru production, a significant contributor to total 268 GHGs is the carbon support, which is assumed to be coal-based for this analysis. Biomass based supports, 269 such as coconut shell carbon, would likely reduce this impact, and GHG analysis of these types of 270 supports is needed. When economic allocation is used, the $\mathrm{Ru} / \mathrm{C}$ catalyst has a carbon footprint that is 271 over 10-fold higher than the $\mathrm{MoS}_{2} / \mathrm{NiS}$ catalyst, primarily due to the high value of Ru (resulting in higher 272 economic allocation of emissions per kilogram of metal) compared to more abundant metals like Ni and 273 Mo. Using mass allocation, the $\mathrm{Ru} / \mathrm{C}$ is over twice as GHG intensive as $\mathrm{MoS}_{2} / \mathrm{NiS}$, primarily due to the 274 high GHG-intensity of the activated carbon compared to that of the alumina. It is important to note that 
these estimates do not consider secondary Ru sources, in particular from metals reclamation of spent catalyst. This could substantially decrease the carbon footprint of the Ru/C catalyst.

\section{$277 \quad 3.2 \quad$ Potential impact of metals reclamation}

278 Energy usage data for catalyst recycling and metals reclamation processes is extremely limited in the 279 open literature and therefore secondary metals sourcing was not considered in the analysis. It is useful, 280 however, to consider the qualitative aspects of catalyst recycling and the potential impact on the catalyst 281 carbon footprint. In the petroleum industry, it is estimated that approximately 45,000 tons of spent

282 hydrotreatment catalyst are processed for metals recovery each year [50]. Recovery of Ni, Co, Mo, and W 283 is accomplished, while alumina is disposed of as an inert slag [50]. The refiner's decision of whether to 284 send catalyst off for metals reclamation depends primarily on the catalyst type (value of metals) and 285 whether the spent catalyst is considered hazardous [51]. Based on the metal values alone, it is anticipated 286 that in the case of ruthenium, spent catalyst would enter the secondary materials processing chain after 287 leaving the refinery, as the cost to replace with virgin material would significantly outweigh the cost to recover. Even with catalysts made from more abundant metals like Ni and Mo, there may be significant savings associated with recovery over disposal, depending on the hazardous nature of the waste.

Catalysts made from secondary metals reclaimed from spent materials are likely to be less energy-

291 intensive than catalysts made from primary metals extraction and refining processes. One study estimates 292 that the GHG emissions associated with catalytic converter metal recovery of secondary PGMs is more 293 than ten-fold lower than those associated with primary PGMs [26]. Therefore, the GHG values presented 294 here likely provide a conservative estimate compared with scenarios that incorporate recycled metals.

\section{$295 \quad 3.3 \quad$ Catalyst impact on biofuel production GHGs}

296 The ultimate goal of this study is to ascertain the relative contribution of hydrotreating catalyst 297 consumption to the fuel production stage GHGs for the fast pyrolysis and bio-oil upgrading process.

298 Using reactor space velocities and catalyst lifetimes from Jones et al. [5], catalyst consumption per gallon 299 of fuel was estimated. Catalyst consumption along with GHG estimates presented in Section 3.1 were 
then incorporated into the conversion stage life cycle for the US Department of Energy’s Bioenergy

301 Technologies Office (BETO) fast pyrolysis and upgrading pathway design case [5]. The detailed GHG

302 LCA for the design case conversion process can be found in [5].

Fig. 9 shows the fossil GHGs associated with the conversion pathway for both the economic and

305 process (see Fig. 1), other stages of the fuel life cycle (e.g., feedstock production, transportation, fuel

306 distribution) are not included here. Furthermore, conversion inputs other than catalyst (see [5] for details)

307 are aggregated to focus only on the catalyst impacts and their relative importance to the total conversion-

308 related GHGs. Note that these results include both direct fossil GHG emissions from the plant and

309 emissions associated with the production of energy and materials used at the plant (e.g., natural gas and

310 electricity). Two cases of hydrotreating catalyst lifetime are included in the analysis to represent the

311 current state of technology and the target maximum thought to be achievable through experimental

312 research. Hydrotreating catalyst lifetime is highly dependent on the quality of the oil being processed.

313 Fast pyrolysis bio-oil contains certain species that cause coking of the catalyst, in particular at the more

314 severe conditions of the $2^{\text {nd }}$ and $3^{\text {rd }}$ stage reactors (after stabilizer). Lifetimes of about 0.2 year are

315 currently being achieved in the laboratory for the $\mathrm{Ru} / \mathrm{C}$ and the $\mathrm{MoS}_{2} / \mathrm{NiS}$ used in these reactors [52]. A

316 target lifetime of 1 year (or equivalent consumption through combined strategies) has been set to help

317 reach BETO’s programmatic 2017 cost target of \$3/gasoline gallon equivalent for the pyrolysis pathway

318 [5]. Research to meet the target is focused on reducing catalyst consumption through a combination of

319 strategies including increasing lifetime, increasing reactor space velocities, reducing Ru loading, and

320 extending time between regenerations [52]. Also shown for comparison in Fig. 9 is the conversion GHGs

321 estimated in the design report [5], for which catalyst was approximated with a zeolite process from the

322 Ecoinvent Version 2.2 database [10]. For the hydrocracking catalyst and steam reforming catalyst, a

323 zeolite process from the Ecoinvent database is still used as a proxy (as in the design case) for lack of more

324 specific data on these catalysts. The GHG intensity of the Ecoinvent zeolite process (“zeolite, powder, at 
plant/RER with US Electricity U”) is $4.19 \mathrm{~kg} \mathrm{CO}_{2}$-e/kg. Transportation of catalyst to the refinery is not included in the analysis.

As shown in Fig. 9, in the case where economic allocation is used for $\mathrm{Ru} / \mathrm{C}$, overall conversion GHGs for pyrolysis and upgrading are estimated at $19.9 \mathrm{~g} \mathrm{CO}_{2}$-e/MJ at the target catalyst lifetime of 1 year. This is an increase of 5\% over the 2013 design case estimate. The shorter lifetime of 0.2 year for the state of technology case results in 14\% higher GHGs compared to the 1 year case. The effect of lifetime is not as evident when mass allocation is used, as the catalyst related GHGs are lower compared to the economic allocation case. For the 1-year base case (using economic allocation), catalyst consumption contributes approximately $6 \%$ to the total conversion GHGs (1\% using mass allocation), with the $\mathrm{Ru} / \mathrm{C}$ catalyst accounting for the majority of this, as shown in Table 7. For the 0.2-year case (using economic allocation), catalyst contribution is much higher at $17 \%$ of the total conversion GHGs (6\% using mass allocation). The catalyst contribution is less significant when considering the entire fuel life cycle (including feedstock production, transportation, and fuel distribution), GHGs for which are are in the range of 28.3-33.3 $\mathrm{g} \mathrm{CO}_{2}-\mathrm{e} / \mathrm{MJ}$ gasoline for forest residue feedstock [5].

Table 7. Catalyst consumption and contribution to conversion GHGs

\begin{tabular}{|c|c|c|c|}
\hline Catalyst & $\begin{array}{l}\text { Consumption } \\
\text { at } 1 \text { yr Life } \\
\text { (lb/gge fuel } \\
\text { produced) }^{\mathrm{a}}\end{array}$ & $\begin{array}{c}\text { GHGs, } \mathrm{gCO}_{2} \text {-e/MJ fuel } \\
\text { (\% of total conversion GHGs) } \\
\text { Economic Allocation for Ru/C }\end{array}$ & $\begin{array}{l}\text { GHGs, } \mathrm{gCO}_{2} \text {-e/MJ fuel } \\
\text { (\% of total conversion } \mathrm{GHGs} \text { ) } \\
\text { Mass Allocation for Ru/C }\end{array}$ \\
\hline $\begin{array}{l}\text { Ru/C (stabilizer and first } \\
\text { stage) }\end{array}$ & 0.004 & $1.04(5.2 \%)$ & $0.18(0.9 \%)$ \\
\hline Ni-Mo (second stage) & 0.005 & 0.10 (0.5\%) & 0.10 (0.5\%) \\
\hline $\begin{array}{l}\text { Hydrocracking (proxy of } \\
\text { zeolite, [10]) }\end{array}$ & 0.00009 & $0.001(0.005 \%)$ & $0.001(0.007 \%)$ \\
\hline $\begin{array}{l}\text { SMR (proxy of zeolite, } \\
{[10] \text { ) }}\end{array}$ & $0.0002^{b}$ & $0.003(0.01 \%)$ & $0.003(0.02 \%)$ \\
\hline Total & 0.009 & $1.15(5.8 \%)$ & $0.28(1.2 \%)$ \\
\hline
\end{tabular}

Based on the results of this analysis, it can be concluded that at the target 1 year catalyst lifetimes, the consumption of Ni-Mo catalyst in the pyrolysis bio-oil upgrading process does not significantly contribute to the conversion stage GHGs, while the contribution of virgin Ru catalyst is more significant 
and should be considered in the analysis when possible, especially when economic allocation is chosen

346 for determining Ru/C GHGs.

\section{$347 \quad 3.4 \quad$ Data quality considerations}

While a quantitative uncertainty analysis is not within the study scope, it is useful to consider the source of the data and qualitatively discuss the relative uncertainty of data sets to aide with the interpretation of the results. The data used in this analysis are taken from a variety of sources, including studies by trade industry organizations, the Ecoinvent database, and the open literature. As the most significant processes contributing to catalyst GHGs are metal precursor production; these are the focus of 353 this discussion.

Data for NiO come from a 2000 LCA study of several nickel products, commissioned by the Nickel

355 Institute [15]. For this study, data were collected from nickel production facilities around the world via questionnaires for all inputs and outputs of each facility. A data quality evaluation was conducted as part of this study, per ISO 14041 guidance [53], and showed that the data were representative of $85 \%$ of western world production. Data for $\mathrm{MoO}_{3}$ are from a study commissioned by the IMOA [19], and similar to the $\mathrm{NiO}$, rely on site data collected via questionnaires sent to processing facilities around the world. These data were deemed to be representative of $90 \%$ of western world production of $\mathrm{MoO}_{3}$. Because the

$361 \mathrm{NiO}$ and $\mathrm{MoO}_{3}$ studies are based primarily on first-hand data collected from multiple facilities from 362 multiple countries, the data for these precursors are expected to be highly reliable. 
mining companies in South Africa, Russia, and Canada, Saurat and Bringezu estimate GHG emissions for

371 global primary PGMs (65\% South Africa, 27\% Russia, and 8\% Canada) at 23,451 kg CO -e/kg PGMs.

372 This is comparable to the GHGs allocated to the global PGM mix assumed in this study from Ecoinvent 373 data (23,000 kg CO 2 -e/kg PGMs for a 78\% South African and 22\% Russian mix).

374 Because the data set for Ni and Mo was collected via direct survey of many industrial facilities, it 375 may be generally more reliable than the Ecoinvent PGM data, which are derived primarily from a 376 seemingly more limited data set. For this reason, GHG results for the $\mathrm{Ru} / \mathrm{C}$ catalyst may have a higher

377 related degree of uncertainty than the NiMo catalyst results. However, the general difference in

378 magnitudes of results seen between the NiMo and Ru catalysts is to be expected, due to the heavy burdens

379 of precious metals compared to more common metals like Ni and Mo. Further, the impact of catalyst

380 consumption on overall fuel GHGs is expected to be in the same approximate range as determined from 381 this study. A more detailed analysis employing a survey-based data collection procedure would help 382 strengthen the $\mathrm{Ru} / \mathrm{C}$ catalyst results. In addition, process data is needed on Ru reclamation from spent 383 catalyst recycling to quantify the impact of secondary sourcing on Ru/C LC GHGs.

$384 \quad$ 4. Conclusions

385 Life cycle GHGs were estimated for two representative examples of potential bio-oil hydrotreating 386 catalysts to determine the impact of catalyst consumption on the GHGs associated with fast pyrolysis and 387 bio-oil upgrading biomass conversion. The GHGs for the $\mathrm{NiMo} / \mathrm{Al}_{2} \mathrm{O}_{3}$ catalyst are estimated to be $5.5 \mathrm{~kg}$ $388 \mathrm{CO}_{2}$-e/kg catalyst. Sensitivity analysis shows that if the catalyst manufacturing energy comes from only 389 electricity, GHGs for the catalyst are 3-13\% higher, depending on the grid mix assumed. At a catalyst 390 lifetime of 1 year, $\mathrm{NiMo} / \mathrm{Al}_{2} \mathrm{O}_{3}$ contributes approximately $0.5 \%$ of the total fuel conversion stage GHGs, 391 a relatively insignificant impact. The Ru/C catalyst GHGs are estimated to be $80.4 \mathrm{~kg} \mathrm{CO}$-e/kg when 392 using economic allocation and $13.7 \mathrm{~kg} \mathrm{CO}_{2}$-e/ $\mathrm{kg}$ when using mass allocation. $\mathrm{Ru} / \mathrm{C}$ has a significant 393 impact on overall conversion GHGs, contributing 5\% of the total conversion stage GHGs when economic 394 allocation is used for $\mathrm{Ru} / \mathrm{C}$. When mass allocation is used for $\mathrm{Ru} / \mathrm{C}$, catalyst contribution is less 
significant (1.2\%). At lifetimes currently being achieved (0.2 yr), conversion stage GHGs are 14\% higher than the 1 year target case (5\% higher for Ru/C mass allocation). This analysis considers only virgin

397 ruthenium in the production of $\mathrm{Ru} / \mathrm{C}$ catalyst and as such provides a conservative GHG estimate. The

398 inclusion of reclaimed metal from spent catalyst recycling is expected to reduce the ruthenium impact. In

399 general, fuel processing catalysts that contain virgin precious metals will have a higher GHG impact than

400 those containing more common metals, especially when economic allocation is used. However, the

401 ultimate GHG contribution of catalysts will depend on the specifics of each application, most importantly

402 a combination of composition, lifetime, and whether metals can be recovered efficiently from spent

403 catalyst. A more detailed assessment involving direct survey and data collection of the PGM industry,

404 including spent catalyst recycling process information, would help to build upon this study.

405 References

406 [1] Zacher AH, Olarte MV, Santosa DM, Elliott DC, Jones SB. A review and perspective of recent

407 bio-oil hydrotreating research. Green Chemistry 2014; 16(2): 491. doi:10.1039/c3gc41

408 [2] Elliott DC. Historical Developments in Hydroprocessing Bio-oils. Energy \& Fuels 2014; 21(3):

$409 \quad$ 1792-1815. doi:10.1021/ef070044u

410 [3] EISA. Energy Independence and Security Act of 2007. Public Law 110-140, 2007.

411 [4] US EPA. Fuel-Specific Lifecycle Greenhouse Gas Emissions Results. Washington, DC; 2010.

412 Docket \# EPA-HQ-OAR-2005-0161-3173. URL:

413 http://www.regulations.gov/\#!documentDetail;D=EPA-HQ-OAR-2005-0161-3173

414 [5] Jones S, Meyer P, Snowden-Swan L, Padmaperuma A. Process Design and Economics for the 415 Conversion of Lignocellulosic Biomass to Hydrocarbon Fuels. Pacific Northwest National

416 Laboratory, Richland, WA.; 2013. Report No. PNNL-23053.

417 [6] Han J, Elgowainy A, Dunn JB, Wang, MQ. Life cycle analysis of fuel production from fast $418 \quad$ pyrolysis of biomass. Bioresource Technology 2013; 133: 421-428.

419 doi:10.1016/j.biortech.2013.01.141 
420 [7] Hsu DD. Life Cycle Assessment of Gasoline and Diesel Produced via Fast Pyrolysis and Hydroprocessing. National Renewable Energy Laboratory, Golden, CO.; 2011. Report No. NREL/TP-6A20-49341. URL: http://www.nrel.gov/docs/fy11osti/49341.pdf

[8] Solomon S, Qin D, Manning M, Chen Z, Marquis M, Averyt KB, Miller HL. Contribution of Working Groups I to the Fourth Assessment Report of the Intergovernmental Panel on Climate Change: Physical Science Basis. New York, USA; Cambridge University Press; 2007. URL: http://www.ipcc.ch/publications and data/publications_ipcc fourth_assessment_report_wg1_rep

428 [9] SimaPro. SimaPro Life Cycle Assessment Software V. 8.0. Amersfoort, Netherlands; Product Ecology Consultants; 2013.

[10] Ecoinvent. Ecoinvent Database Version 2.2. Hamburg, Germany; Swiss Center for Life Cycle Inventories; 2011.

432 [11] Ecoinvent. Ecoinvent Database Version 3.1. Hamburg, Germany; Swiss Center for Life Cycle Inventories, 2014.

434 [12] National Renewable Energy Laboratory. U.S. Life Cycle Inventory Database. Golden, CO; 2012. URL: https://www.lcacommons.gov/nrel/search

[13] Earthshift. US-EI Database. Huntington, VT. URL: http://www.earthshift.com/software/USEIdatabase.

[14] Joint Research Centre. European Life Cycle Database. Ispira, Italy. URL: http://eplca.jrc.ec.europa.eu/?page id=126.

[15] Nickel Institute. LCI of Nickel Products. Toronto, Ontario, Canada; 2000. URL: http://www.nickelinstitute.org/Sustainability/LifeCycleManagement/LifeCycleData/LCI_Project2 $\underline{\text { 000/NickelproductsLCIreport/LciTables.aspx }}$

Glaister BJ, GM Mudd. The environmental costs of platinum-PGM mining and sustainability: Is the glass half-full or half-empty?” Minerals Engineering 2010; 23: 328-450. 
[17] Crundwell FK, Moats MS, Ramachandran V, Robinson TG, Davenport WG. Extractive Metallury of Nickel, Colbat, and Platinum-Group Metals. Oxford, UK: Elsevier; 2011, p. 243.

[18] Gabrielov AG, Bhan OK. Preparation of a Hydrotreating Catalyst. US Patent. 6,218,333 B1, April 17, 2001.

[19] International Molybdenum Association. Life Cycle Inventory of Molybdenum Chemicals Summary Report. IMOA LIfe Cycle Assessment Program, London, UK; 2006. URL: http://www.imoa.info/HSE/LCI/download-executive-summaries.php

[20] Ecobalance Inc. Life Cycle Assessment of Nickel Products. Bethesda, MD; 2000. URL: http://www.nickelinstitute.org/en/Sustainability/LifeCycleManagement/LifeCycleData/LCI_Proje ct2000/NickelproductsLCIreport/NickelproductsLCIreport-PDF.aspx

[21] Jones RT. Platinum smelting in South Africa. South African Journal of Science 1999; 95: 525534.

[22] European Commission. Report on Critical Raw Materials for the EU: Report of the Ad hoc Working Group on defining critical raw materials. 2014. URL: http://ec.europa.eu/enterprise/policies/raw-materials/critical/index en.htm

[23] Classen M, Althaus H, Blazer S, Scharnhorst W, Matthias T, Jungbluth N, Emmenegger M. Life Cycle Inventories of Metals. Ecoinvent, Zurich, Switzerland; 2007. Ecoinvent v2.0 Report No. 10.

[24] Tuusjarvi M, S Vuori, I Maenpaa. Metal Mining and Environmental Assessments: A New Approach to Allocation. Journal of Industrial Ecology 2012; 16(5): 735-747.

[25] Fthenakis V, W Wang, HC Kim. Life cycle inventory analysis of the production of metals used in photovoltaics. Renewable and Sustainable Energy Reviews 2009; 13: 493-517.

[26] Saurat M, Bringezu S. Platinum Group Metal Flows of Europe, Part I: Global Supply, Use in Industry, and Shifting of Environmental Impacts. Journal of Industrial Ecology 2008; 12(5/6): 754-767. 
[27] Althaus H, M Classen. Life Cycle Inventories of Metals and Methodological Aspects of Inventorying Material Resources in ecoinvent. International Journal of Life Cycle Assessment 2005; 10(1): 43-49.

[28] Amatayakul W, O Ramnas. Life cycle assessment of a catalytic converter for passenger cars. Journal of Cleaner Production 2001; 9: 395-403.

[29] PE International. Harmonization of LCA Methodologies for Metals: A whitepaper providing guidance for conducting LCAs for metals and metal products. Leinfelden-Echterdingen, Germany; 2014. Version 1.01. URL: http://www.imoa.info/HSE/LCI/harmonization-of-LCAMethodologies-for-Metals.php

[30] Ardente F, M Cellura. Economic Allocation in Life Cycle Assessment: The State of the Art and Discussion of Examples. Journal of Industrial Ecology 2011; 16(3): 387-398.

[31] Johnson Matthey. PGM Price Tables. London, UK; 2014. URL: http://www.platinum.matthey.com/prices/price-tables

[32] Wildschut J, I Melian-Cabrera, HJ Heeres. Catalyst studies on the hydrotreatment of fast pyrolysis oil. 2010; Vol. 99: 298-306.

[33] Griffith WP. Ruthenium Trichloride and Its Applications. Platinum Metals Review 1975; 19(2): $60-62$.

[34] Bell WE, Garrison MC, Merten U. Thermodynamic Properties of Gaseous Ruthenium Chlorides at High Temperature. Journal of Physical Chemistry 1961; 65(3): 517-521. doi:10.1021/j100821a029

[35] Bayer P, Heuer E, Karl U, Finkel M. Economical and ecological comparison of granular activated carbon (GAC) adsorber refill strategies. Water Research 2005; 39(9): 1719-28. doi:10.1016/j.watres.2005.02.005

[36] Portefaix JL, M Cattenot, JA Dalmon, C Mauchausse. Influence of the support and the sulphidation temperature on the catalytic properties of molybdenum sulphide in pyridine hydrogenation and piperidine hydrodenitrogenation. Studies in Surface Science and Catalysis. 
Hydrotreating Catalysts; Preparation, Characterization and Performance Proceedings of the Annual International AIChE Meeting, Washington, DC, November 27-December 2, 1988. Vol. 50. ML Occelli, RG Anthony, eds.. Elsevier, Amsterdam, Netherlands. 1989. p. 68

[37] Luck F, F Viez. Preparation of Hydrotreating Catalysts by Kneading. Characterization of the oxidic phase by laser raman, x-ray photoelectron and uv-visible spectroscopies. Studies in Surface Science and Catalysis. Structure and Reactivity of Surfaces. Proceedings of a European Conference, Trieste, Italy. September 13-16, 1988. Vol. 48. C Morterra, A Zecchina, G Costa, eds. Elsevier, Amsterdam, Netherlands. 1989. p. 611.

38] Magee JS, GE Dolbear. Petroleum Catalysis in Nontechnical Language. PenWell Publishing Co., Tulsa, OK; 1998.

Lodeng R, L Hannevold, H Bergem, M Stocker. Catalytic Hydrotreatment of Bio-Oils for HighQuality Fuel Production. Chapter 11, In The Role of Catalysis for The Sustainable Production of Bio-fuels and Bio-chemicals, Elsevier B.V., Amsterdam, The Netherlands; 2013.

[40] Gao Y, X Fang, Z Cheng. Development and application of ex-situ presulfurization technology for hydrotreating catalysts in China. Fron. Chem. Sci. Eng. 2011; 5(3): 387-396.

[41] Heinrich G, S Kasztelan. Hydrotreating. Chapter 16, In “Conversion Processes,” Petroleum Refining,” Vol. 3, P Leprince, ed., TECHNIP, France; 2010.

[42] Argonne National Laboratory. The Greenhouse Gases, Regulated Emissions, and Energy use in Transportation (GREET) Model. Argonne, IL; 2013.

[43] Aspentech. Aspen Plus. Burlington, MA; 2013. URL: http://www.aspentech.com/products/aspen-plus.cfm

[44] Schwartz JT Ru,Re/Carbon Catalyst for Hydrogenation in Aqueous Solution. US Patent 5,478,952. Dec. 26,1995.

[45] Primo A, P Concepcion, A Corma. Syngergy between the metal nanoparticles and the support for the hydrogenation of functionalized carboxylic acids to diols on Ru/TiO2. Chem. Commun. 2011; 47: 3613-3615. 
522 [46] Zhang Z, JE Jackson, DJ Miller. Aqueous-phase hydrogenation of lactic acid to propylene glycol. Applied Catalysis A 2001; 219: 89-98.

[47] Johnson Matthey. Calculating our Carbon Footprint at Clitheroe. Sustainability. London, UK; 2009. URL: http://www.matthey.com/Sustainability2009/case-studies/environment_cs_11.html

[48] Lavery NP, Jarvis DJ, Brown SGR, Adkins NJ, Wilson BP. Life cycle assessment of sponge nickel produced by gas atomisation for use in industrial hydrogenation catalysis applications. Int J Life Cycle Assess 2012; 18(2):362-376. doi:10.1007/s11367-012-0478-8

[49] U.S. Environmental Protection Agency. Emissions \& Generation Resource Integrated Database (eGRID 2012). 2015. http://www.epa.gov/energy/egrid

[50] Stiles AB, Koch TA. Catalyst Manufacturing., New York: Marcel Dekker, Inc.; 1995.

[51] Bader N. Catalyst Handling, Disposal Become More Important in Environmental Era. Oil \& Gas Journal 1996, 64-66.

[52] Jones, SB, LJ Snowden-Swan, PA Meyer, AH Zacher, MV Olarte, and C Drennan. Fast Pyrolysis and Hydrotreating: 2014 State of Technology R\&D and Projections to 2017. Pacific Northwest National Laboratory, Richland, WA. 2015. Report No. PNNL-24176.

[53] International Standards Organization. International Standard ISO 14044, Environmental management - Life cycle assessment - Requirements and guidelines. First edition, 2006-07-01. International Standards Organization, Geneva, Switzerland.

\section{Acknowledgements}

The authors gratefully acknowledge the US Department of Energy Bioenergy Technologies Office for their support of this work. This work was conducted under U.S. Department of Energy contract DEAC05-76RL01830. The authors would also like to thank the IMOA and Anne Landfield Greig of Four Elements Consulting, LLC for the use of their molybdenum oxide life cycle inventory data for this study. We very much appreciate the technical review of this work by the following colleagues: John Frye, 
546 Mariefel Olarte, Corinne Drennan, and Alan Zacher, all of Pacific Northwest National Laboratory. We 547 also are grateful for the help of Matt Wilburn (PNNL) on the editorial preparation of this manuscript. 


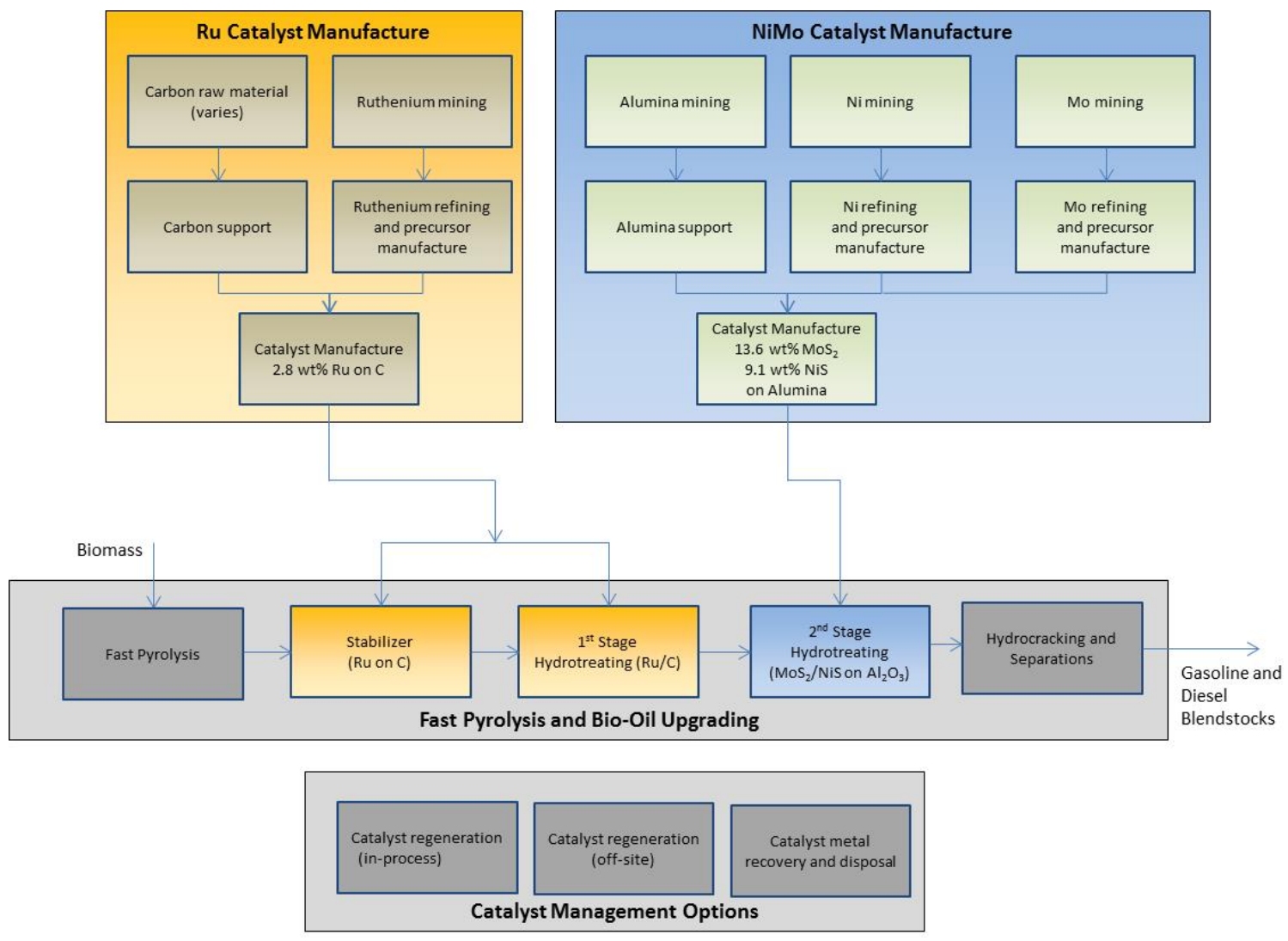

Fig. 1. Pyrolysis oil hydrotreating catalyst life cycle.

551 


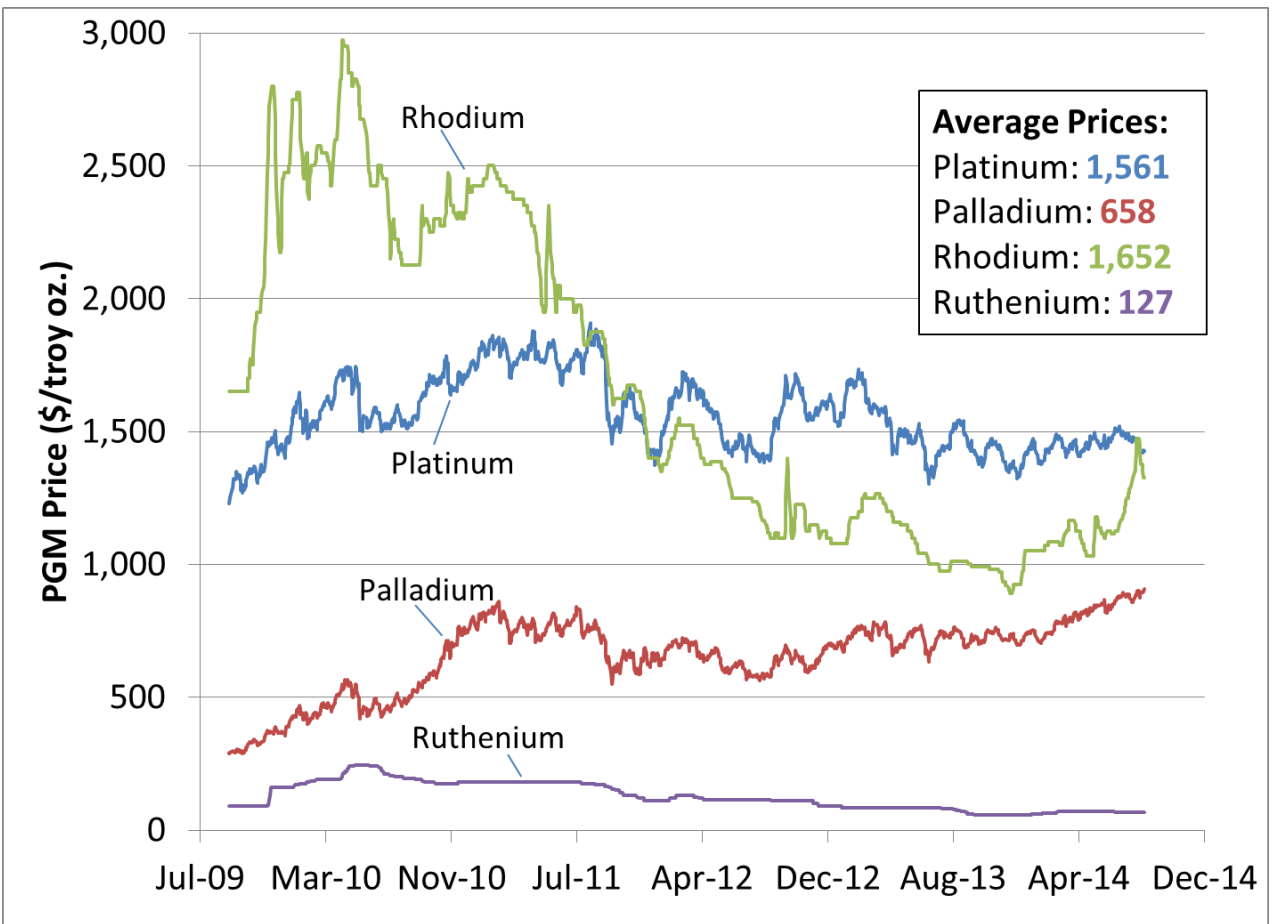

553

Fig. 2. Five-year daily price history for PGMs (Johnson Matthey PGM Price Tables 2014 [31]).

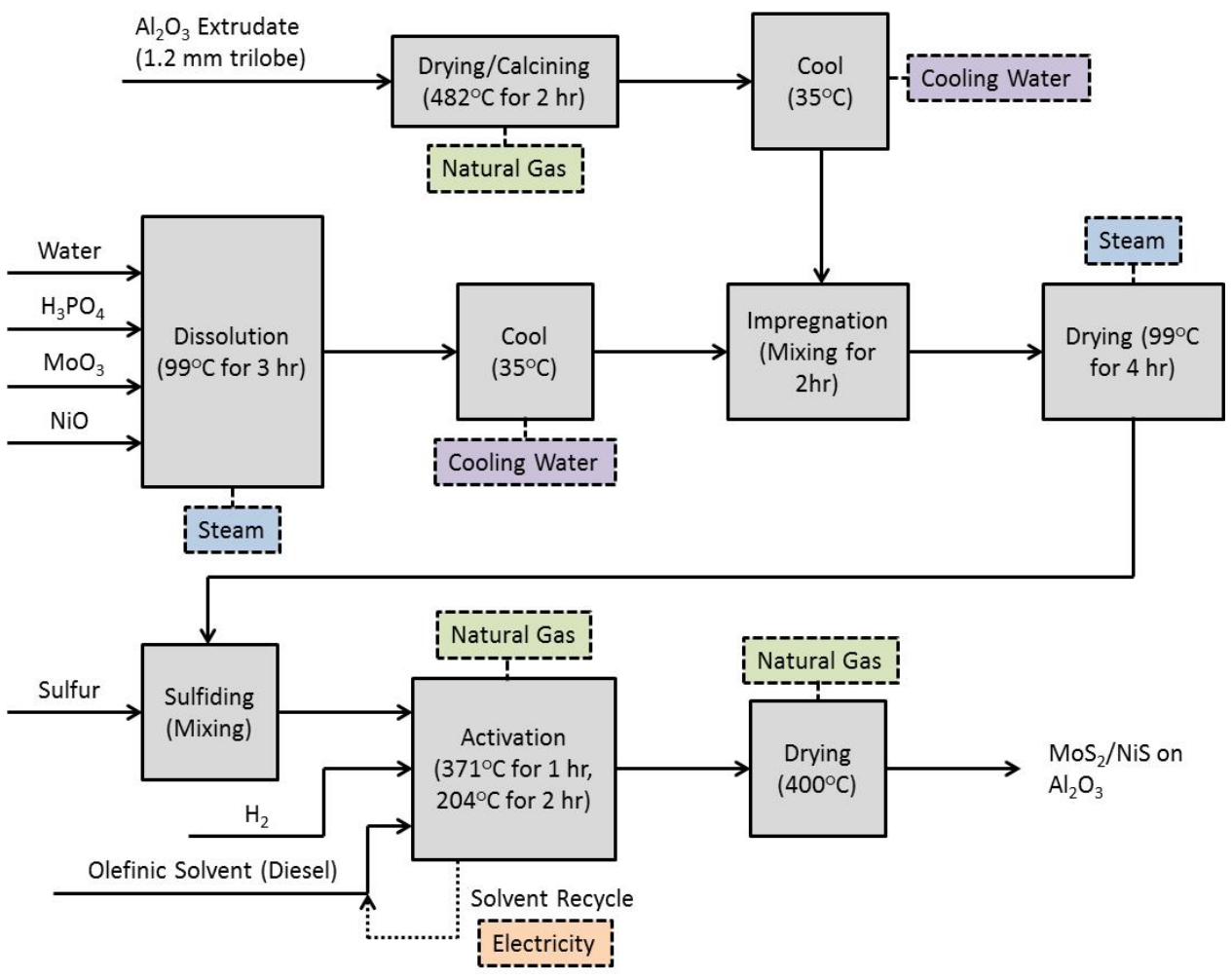




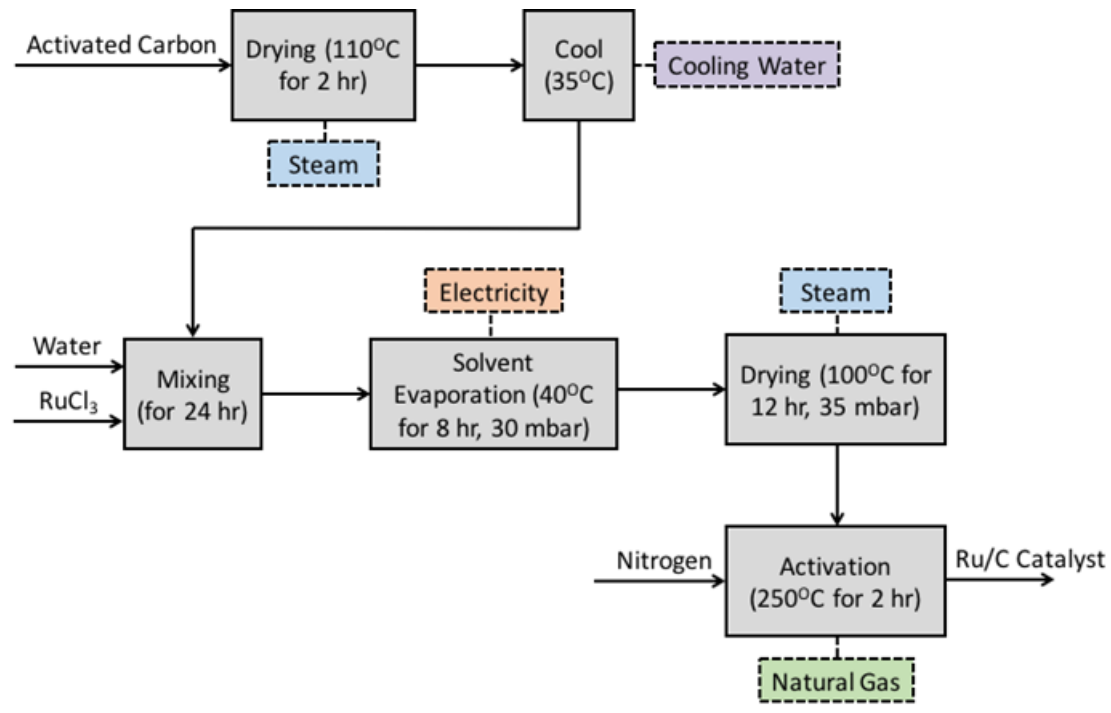

Fig. 4. Preparation of Ru/C (Wildschut [32]).

\begin{tabular}{|ll|}
\hline & \\
\end{tabular}

Fig. 5. Life cycle GHGs for $\mathrm{MoS}_{2} / \mathrm{NiS}$ on $\mathrm{Al}_{2} \mathrm{O}_{3}$. 


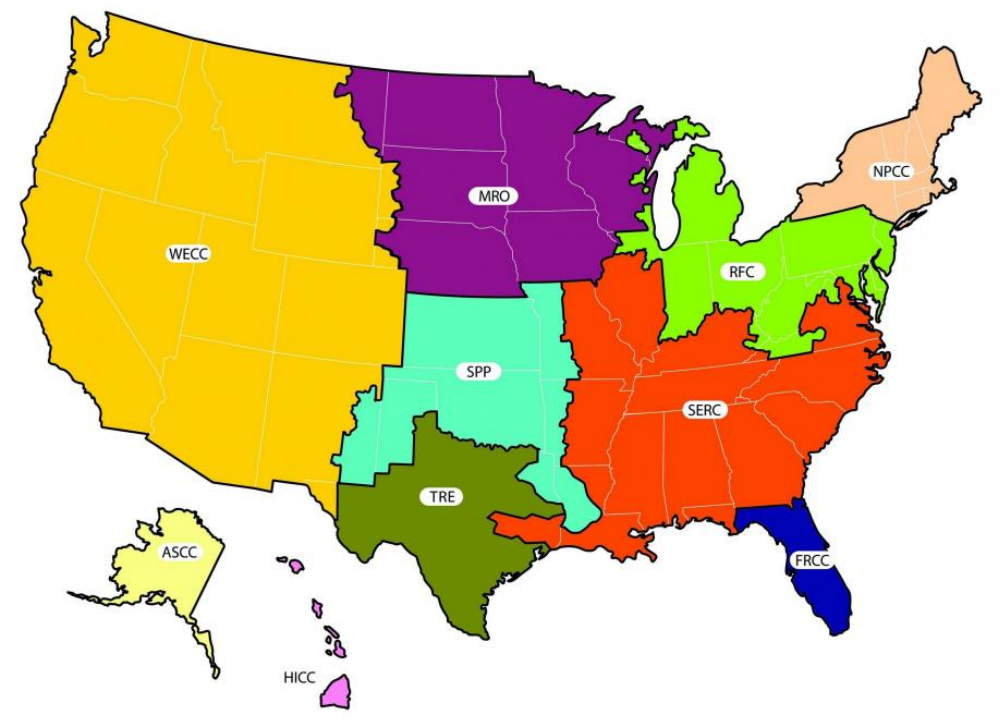

561

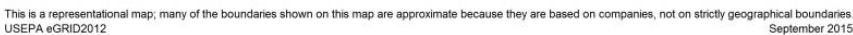

Figure 6. NERC regions for electricity grid mix sensitivity [49].

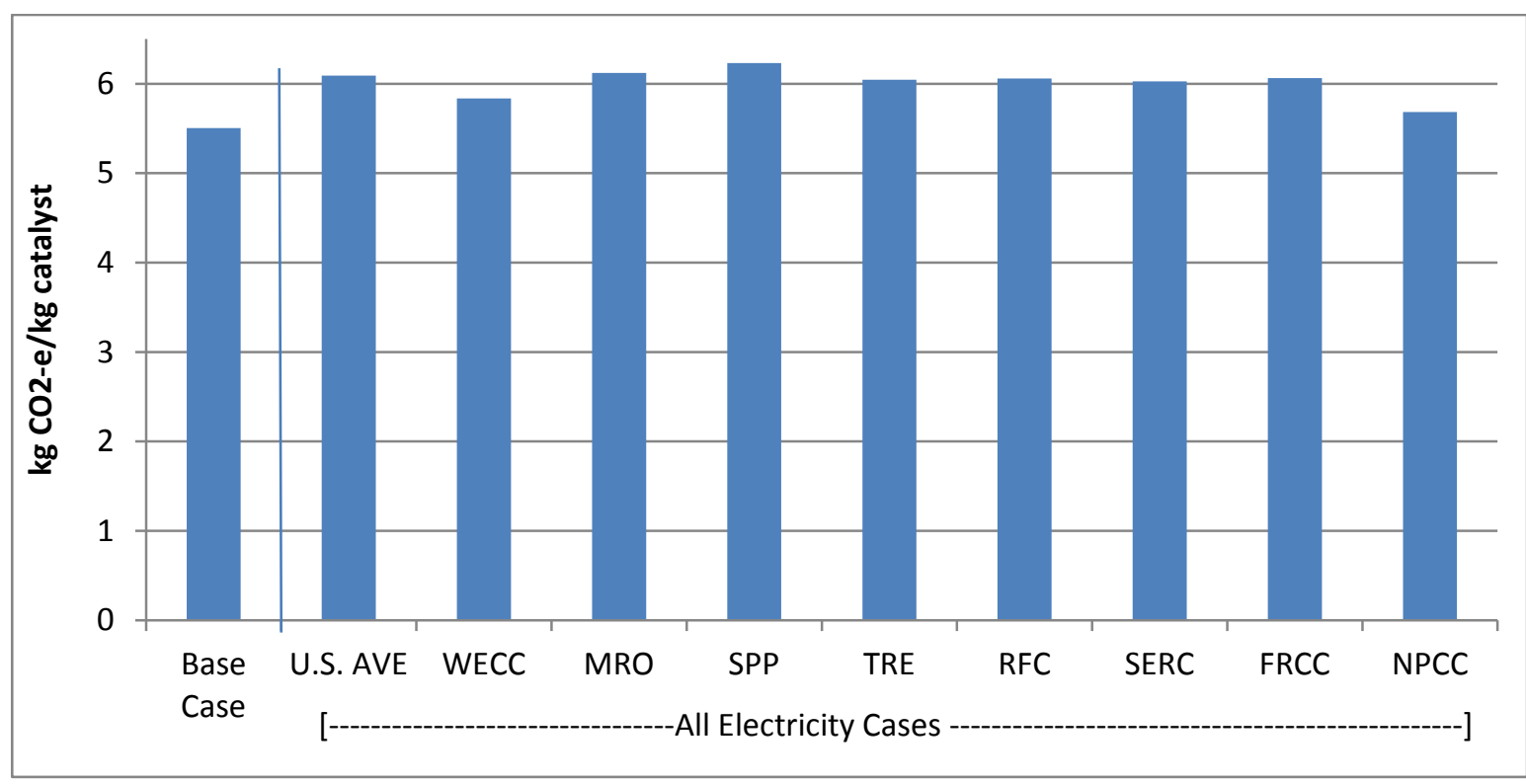

Fig. 7. Sensitivity of $\mathrm{MoS}_{2}$ /NiS GHGs to energy mix used for catalyst manufacturing. 


\begin{tabular}{|l|l|l|}
\hline & & \\
& & \\
\end{tabular}

Fig. 8. Life cycle GHGs for Ru/C catalyst.

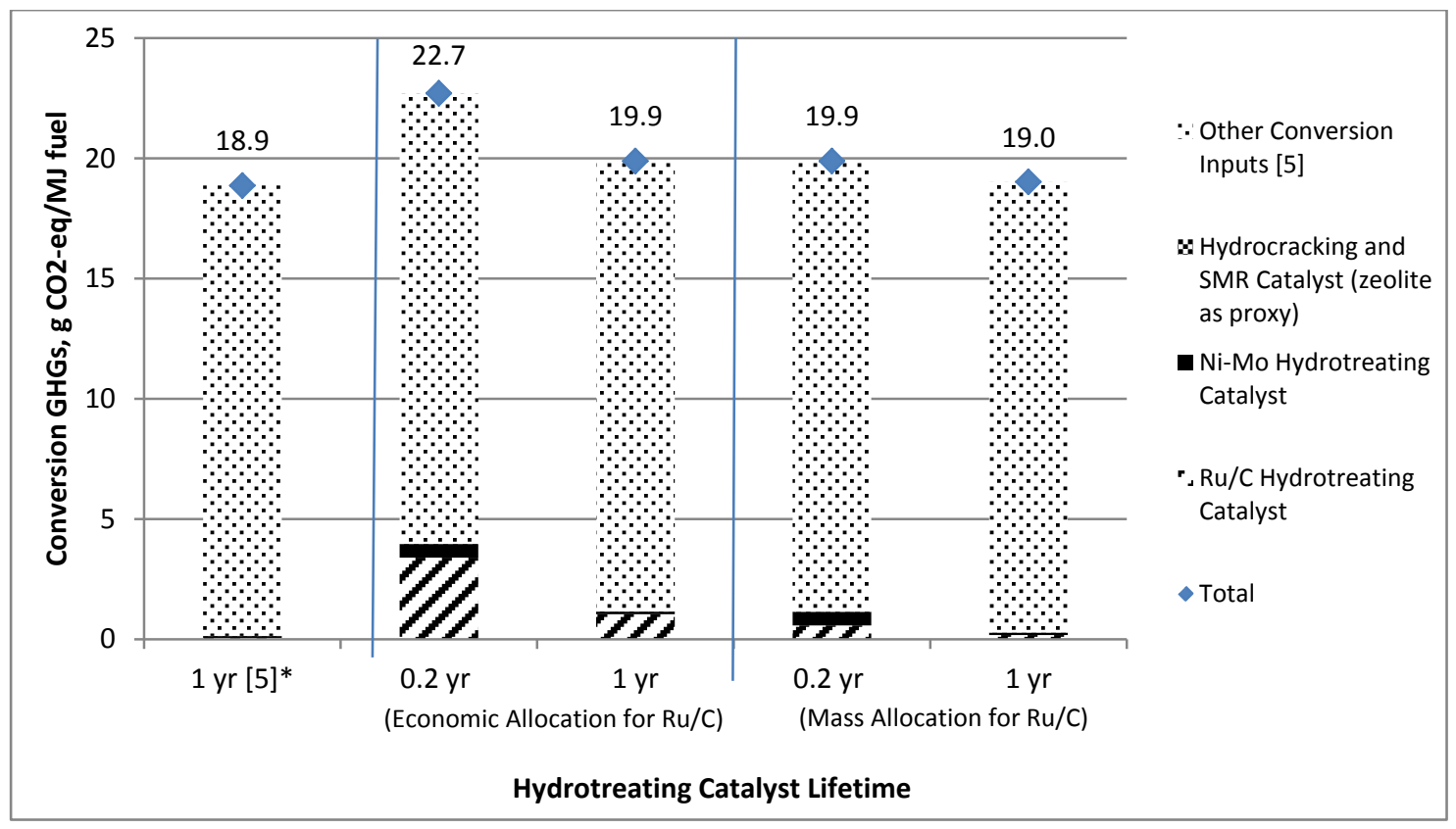

$569 *$ Original conversion GHGs were estimated in the design case using a zeolite as a proxy for all catalysts (Ecoinvent $570[10])$

571 Fig. 9. Catalyst contribution to biomass-to-fuel conversion GHGs for fast pyrolysis and upgrading 
